\title{
Establishment of equilibrium states and effect of disturbances on benthic diatom assemblages of the Torna-stream, Hungary
}

\author{
Edina Lengyel · Judit Padisák • \\ Csilla Stenger-Kovács
}

Received: 4 August 2014/Revised: 25 September 2014/ Accepted: 1 October 2014/Published online: 22 October 2014

(C) The Author(s) 2014. This article is published with open access at Springerlink.com

\begin{abstract}
This paper analyses the establishment of equilibrium states in relation to natural disturbances in epilithic diatom assemblages. Sterilized limestone bricks were exposed between April 2008 and 2009 in the Torna-stream and were removed one by one on every third day in the first month and then weekly until May 2010. Physical and chemical parameters were measured on the field and in laboratory. Equilibrium states were restricted to three separate months: July 2008, May and January 2009 taking the consistence of biomass (chlorophyll-a) into consideration. Cocconeis placentula sensu lato, Fragilaria vaucheriae, Gomphonema parvulum, G. olivaceum, Navicula gregaria, N. lanceolata, Nitzschia linearis, and Surirella brebissonii took part in the equilibrium assemblages, two of which dominated by a single species. Analyses of environmental constancy during equilibrium phases
\end{abstract}

Guest editor: Koen Martens / Emerging Trends in Aquatic Ecology

E. Lengyel $(\bowtie) \cdot J$. Padisák Limnoecology Research Group, MTA-PE, Egyetem Str. 10, Veszprém 8200, Hungary e-mail: lengyele@almos.uni-pannon.hu

J. Padisák

e-mail: padisak@almos.uni-pannon.hu

J. Padisák · C. Stenger-Kovács

Department of Limnology, University of Pannonia,

Egyetem Str. 10, Veszprém 8200, Hungary

e-mail: stenger@almos.uni-pannon.hu allowed concluding that resilience of a developed equilibrium phase may ensure biotic constancy even though the underpinning environmental background fluctuates at higher amplitude. The conclusions of our study on attached stream diatom assemblages are similar to those found for temperate lakes: equilibrium states are rare, unpredictable, ephemeral, may occur both in relatively stable and strongly fluctuating environments, and are mostly characterized by monodominance, but contrary to phytoplankton, their establishment requires a longer time to develop corresponding to differences in generation times.

Keywords Benthic diatom assemblages . Equilibrium state $\cdot$ Disturbance $\cdot$ Environmental constancy

\section{Introduction}

Implementation of the Water Framework Directive (WFD, 2000) initiated a number of phytobenthos surveys in European countries (e.g. King et al., 2006; Kelly et al., 2008, 2009; Várbíró et al., 2012). One of the most robust arguments for using diatoms in ecological status assessment is their high species number. Although methods of status assessment from sampling to data analyses, including the applied indices, improved markedly, the underlying ecological knowledge has remained incomplete (Kelly, 
2013). Until now, process-based research on relationships between environmental factors, population dynamics, and community attributes has been largely missing. For example, except for a very early study (Ács \& Kiss, 1993) the effect of disturbances is poorly understood, especially in relation to the opportunity of development equilibrium states. In phytoplankton, prevalence of equilibrium states is authoritative and basically determines the sampling period (Padisák et al., 2006) for WFD status assessment.

Hardin's (1960) Competitive Exclusion Principle (only as many species may co-exist as the number of limiting resources) predicts equilibrial plant communities with low species number. However, plant communities typically consist of many species in Nature. This contradiction is well known as the Paradox of Plankton (Hutchinson, 1961). For its explanation, a number of equilibrium and non-equilibrium theories were proposed (Hutchinson, 1961; Richerson et al., 1970; Wilson, 1990). The non-equilibrium theories attribute basic role to disturbances (e.g. current velocity) preventing competitive exclusion. According to Connell's (1978) intermediate disturbance hypothesis (IDH), in absence of disturbance diversity will be reduced by competitive exclusion. When disturbance is very frequent, only pioneer species can establish resulting also in low diversity. This hypothesis predicts that the communities reach maximal diversity at disturbances with intermediate frequency and intensity. Considering the relatively high number of diatom species in phytobenthos samples, logic suggests that we monitor disturbed, non-equilibrium diatom communities where separation of causes and consequences is doubtful (Reynolds et al., 1993).

Disturbance can be measured as response of the association to alternating forces (Juhász-Nagy, 1993). It is a complex variable: the origin of the disturbance is less important than its presence, frequency, and intensity (Sommer et al., 1993). After any kind of disturbance, the recovery of community is strongly controlled by the succession processes (Odum, 1969, 1971).

Case studies evidenced that in natural phytoplankton communities it is very difficult to delimit equilibrium phases mostly because of the insufficient sampling frequency and absence of physical and chemical background data. As recommended for phytoplankton communities by Sommer et al. (1993), in the equilibrium phase (i) a maximum of three species contribute more than $80 \%$ of the total biomass, (ii) for at least 2 weeks, (iii) without significant variation in total biomass. These conditions were widely tested by the scientists, but as these criterions proved to be too strict, some modifications were allowed. Based on several studies (Morabito et al., 2003; Naselli-Flores et al., 2003; Nixdorf et al., 2003), increasing the number of co-dominating species to 4-5 was necessary. Furthermore, the generation time of the species in a phytoplankton and in a periphyton community is different. For this reason, the 2 weeks constancy required for phytoplankton have to be increased to 4-5 weeks for attached diatoms. Mischke \& Nixdorf (2003) allowed $\pm 15 \%$ variation in constancy of the total biomass.

Investigations of the equilibrium phases of stream diatoms are not to be found. Since environmental parameters of a stream ecosystem often change suddenly and significantly, we hypothesize that the equilibrium communities cannot develop or occur only very rarely.

\section{Materials and methods}

The sampling site for this study was the midland Torna-stream, in the area of the town Devecser, Hungary $\left(\mathrm{N} 47^{\circ} 06,612^{\prime}, \mathrm{E} 17^{\circ} 26,154^{\prime}\right.$, altitude $170 \mathrm{~m}$; Stenger-Kovács et al., 2013). Semi-natural limestone bricks were used as substratum. The size of the bricks is $10 \times 10 \times 3 \mathrm{~cm}$, the surface is flat with minimal roughness. The measured roughness was 1.019 (Látos, 2012) according to Shelly (1979). Prior to the experiments, the stones were sterilized by cc. hydrogen peroxide, heat treatment $\left(120^{\circ} \mathrm{C}\right)$ and UV light.

From April 2008 to May 2009, 62 phytobenthos samples were taken (first period), and further 50 samples were collected between April 2009 and May 2010 (second period). The limestone bricks were collected randomly one by one every third day in the first month, and then weekly. Diatom valves were cleaned by hot hydrogen peroxide method, and embedded in $\mathrm{Zrax}^{\odot}$ rasin. At least 400 valves per slide were counted with Nixon light microscope $(1,000 \times$ magnification). The species were identified according to the Süßwasserflora von Mitteleuropa (Krammer \& Lange-Bertalot, 1991, 1997, 1999a, b), Iconographia Diatomologica (Lange-Bertalot, 2000a, b, 2004, 2008), Diatoms of Europe (Lange-Bertalot, 2000a, b, 2001, 2002), and Diatomeen im Süßwasser- 
Benthos von Mitteleuropa (Hofmann et al., 2011). Three parameters (length, breadth, and girdle) of ten specimens were measured, and their volumes were calculated following the formulas in the NAWQA program (2001). Biomass data were obtained as the product of relative individual numbers among the 400 valves and biovolume data. Establishment of equilibrium phases was based on data expressing relative contribution to total biomass, and these data were used to separate dominants $(>5 \%)$, frequent species $(1-5 \%)$, and rare species $(<1 \%)$. The net growth rates of the species were calculated based on the exponential equation of population growth described by Malthus (1873) and Turchin (2001).

Water temperature $\left({ }^{\circ} \mathrm{C}\right), \mathrm{pH}$, dissolved oxygen (DO, $\mathrm{mg} \mathrm{l}^{-1}$ ), oxygen saturation (DO\%) and conductivity $\left(\mu \mathrm{S} \mathrm{cm}^{-1}\right.$ ) were measured on the field by HQd 40 Field Case mobile set. $\mathrm{NO}_{2}{ }^{-}, \mathrm{NO}_{3}{ }^{-}, \mathrm{SRP}, \mathrm{TP}, \mathrm{SRSi}$, and $\mathrm{NH}_{4}{ }^{+}$were quantified with spectrophotometry (APHA, 1998; Wetzel \& Likens, 2000), and $\mathrm{Cl}^{-}, \mathrm{SO}_{4}{ }^{2-}$, COD, and alkalinity with titrimetry (APHA, 1998). The regional Water Authority provided daily discharge data. The chlorophyll- $a$ content of the epilithon was extracted directly from the substratum surface with $90 \%$ acetone (Üveges \& Padisák, 2011), and was measured according to Wetzel and Likens (2000 using a Metertech UV/VIS Spektrophotometer, SP8001). To avoid the impact of pheopigments, the acid method was applied (Lorenzen, 1967; Tett et al., 1975).

Principal component analysis (PCA) was carried out by Minitab ${ }^{\circledR}$ Statistical Software program free version 15 (Minitab, Inc., State College, PA), the detailed results of which can be read in Stenger-Kovács et al. (2013).

\section{Results}

Altogether 100 diatom species were identified. The average number of the species was $25 \pm 5$ in the first year, while it was $28 \pm 9$ in the second year. In the first year, arithmetic mean of Shannon-Weaver diversity was $3.41 \pm 0.5$, while in the second year it was $2.99 \pm 1.05$.

Fulfilment of the first and second conditions of equilibrium state

The following species contributed equilibria: (Fig. 1): Gomphonema olivaceum (GOLI), Gomphonema parvulum (GPAR), Diatoma tenuis (DITE), Fragilaria vaucheriae (FCVA), Navicula cryptotenella (NCRY), Navicula gregaria (NGRE), Navicula lanceolata (NLAN), Surirella brebissonii (SBRE), Cocconeis placentula sensu lato (CPLI), Planothidium frequentissimum (PLFR), Ulnaria ulna (FULN), and Nitzschia linearis (NLIN). CPLI, FCVA, and NLAN were most frequently the dominant species during almost the whole first year (Fig. 1). In January, Gomphonema parvulum was replaced by Gomphonema olivaceum. Ulnaria ulna, Diatoma tenuis, and Planothidium frequentissimum were abundant only occasionally.

In the second year, Diatoma tenuis, Ulnaria ulna, and Planothidium frequentissimum did not appear among the dominant species; Navicula cryptotenella and Nitzschia linearis appeared as new members in the assemblage. Gomphonema olivaceum showed a similar seasonal dynamics as in the first period (Fig. 1).

According to the first assumption, $80 \pm 10 \%$ of the biomass should consist of no more than 5 species (Fig. 2). In 2008, the cumulative values of the 5 dominant species usually reached $72 \%$ of the biomass, except in October and February. Diversity did not change significantly (its variation did not exceed 10\%) from June to December: It varied commonly between 3.46 and 3.96. In the first month, and from January to April, the diversity was lower (average 2.95). Next year, there was a long period (from June to October 2009) when this cumulative contribution did not reach this limit value $(<72 \%)$. The diversity was high (more than 3.28) during this period. When the cumulative biomass of the five species reached $72 \%$ of the total biomass, the diversity significantly decreased $(r=-$ 0.81 ); it was lower than 2.72 .

Third condition of equilibrium state

Chlorophyll- $a$ content increased during the vegetation period in both years (Fig. 3). Annual average chlorophyll- $a$ was higher in the second year. In the first period, there were two significant peaks: one in late summer $\left(94 \mu \mathrm{g} \mathrm{cm}^{-2}\right)$, and the other in the next April $\left(69 \mu \mathrm{g} \mathrm{cm}^{-2}\right)$. In the second year, the chlorophyll$a$ content reached its maximum amounts in November $\left(42 \mu \mathrm{g} \mathrm{cm}^{-2}\right)$ and in January $\left(37 \mu \mathrm{g} \mathrm{cm}^{-2}\right)$.

In the first year (Fig. 3A), monthly biomass was constant (biomass variation $<15 \%$ ) only in July, when the average value of chlorophyll- $a$ was $7 \mu \mathrm{g} \mathrm{cm}^{-2}$. In the second year (Fig. 3B), monthly biomass did not 


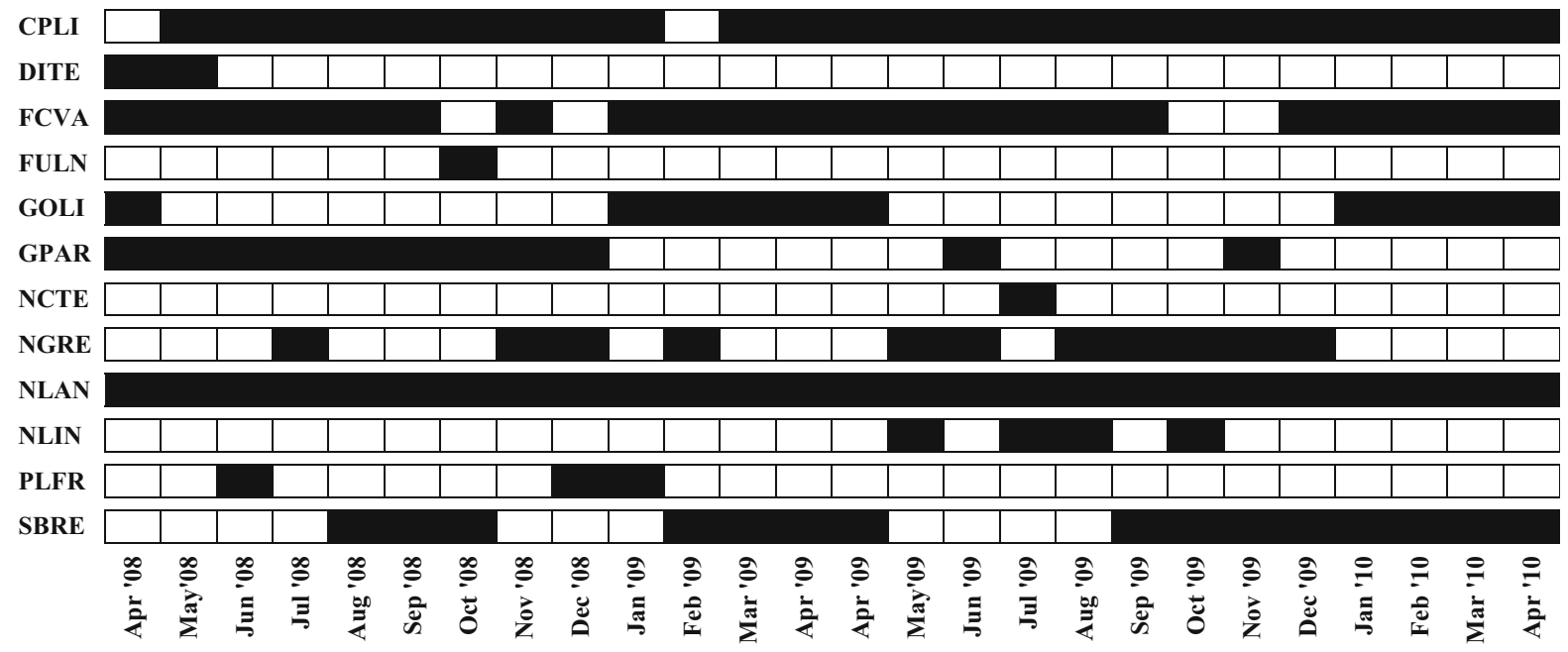

Fig. 1 Species compositions of the diatom community considering no more than five species (cumulative contribution to total biomass $>80 \%$ )
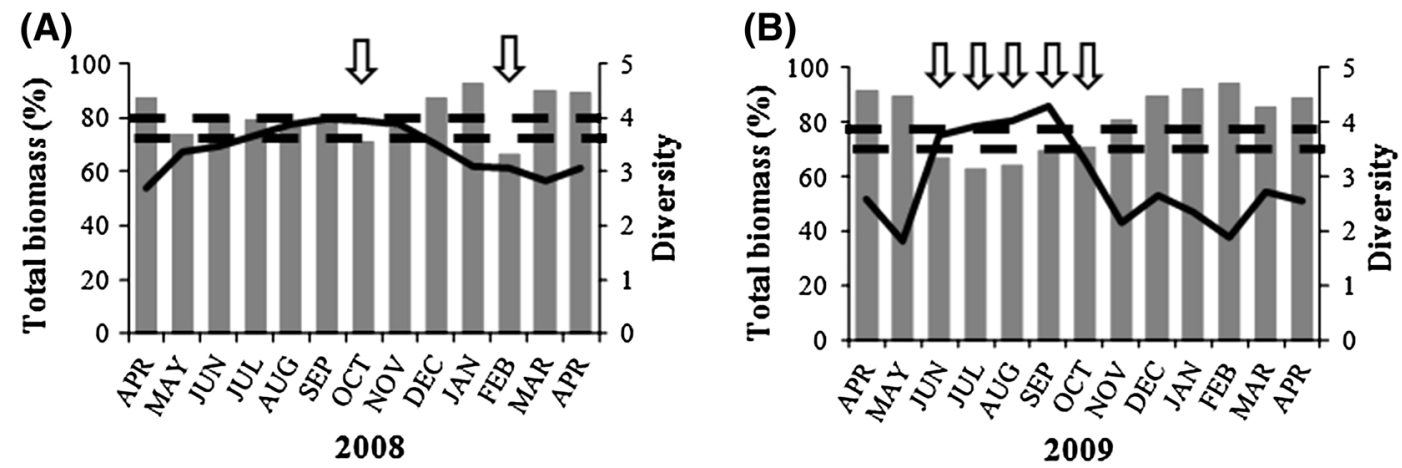

Fig. 2 Contribution of the five most dominant species to the total biomass (grey bars), and Shannon diversity (black line) during the first (A) and second (B) year (line 80\%, broken line 72\%, arrow month where the first condition did not occur)
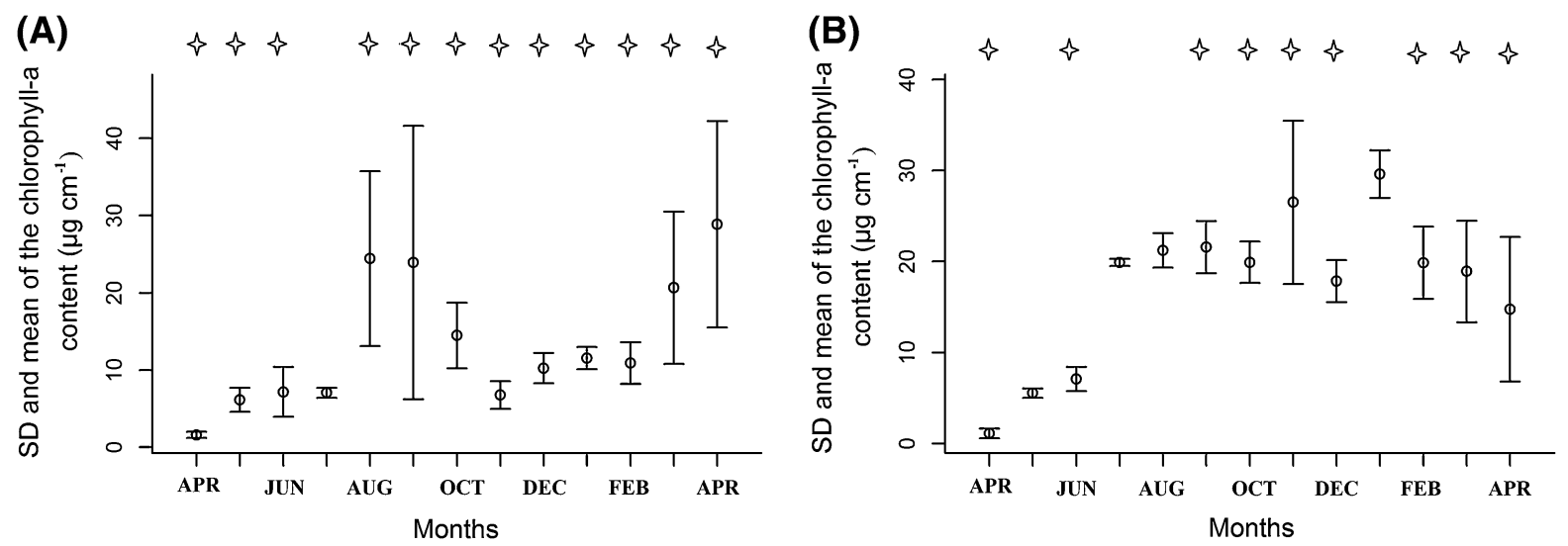

Fig. 3 Mean and the SD of chlorophyll- $a$ content in the first (A) and the second period (B) (star month when the biomass changed significantly) 

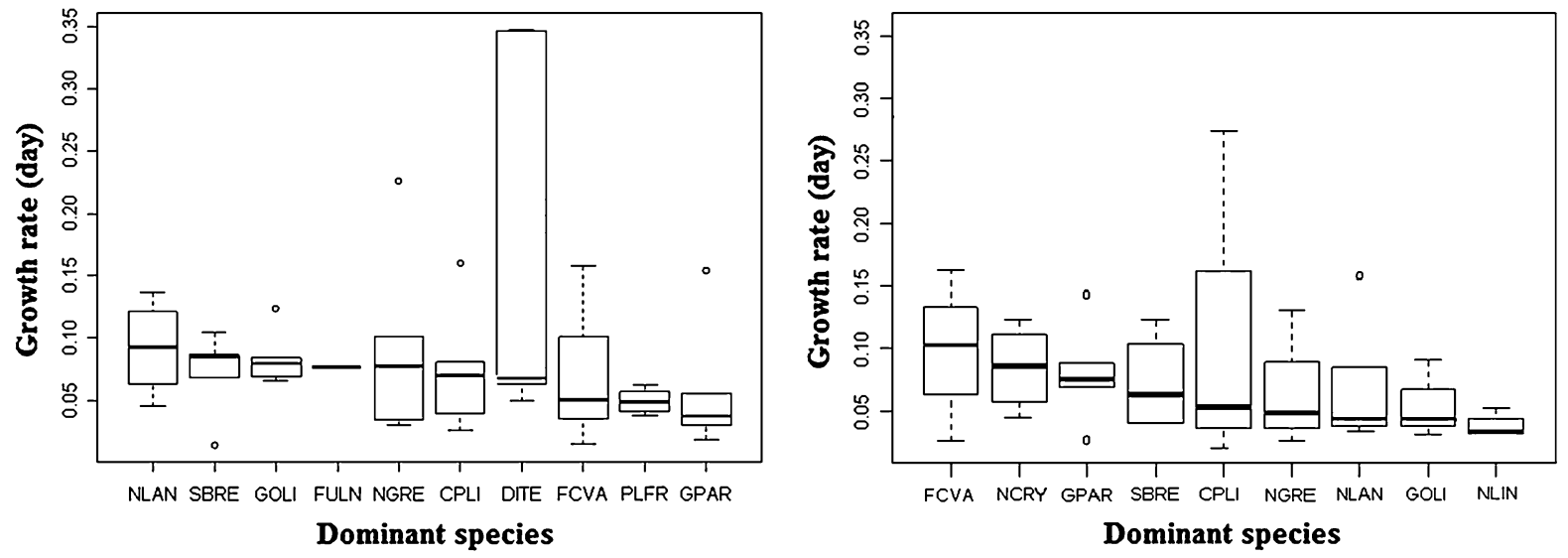

Fig. 4 The net growth rates $(k)$ of the dominant species in the first and the second year in descending order

change significantly in May (average chlorophyll- $a$ : $\left.6 \mu \mathrm{g} \mathrm{cm}^{-2}\right)$, July $\left(20 \mu \mathrm{g} \mathrm{cm}^{-2}\right)$, August $\left(21 \mu \mathrm{g} \mathrm{cm}^{-2}\right)$, and January $\left(30 \mu \mathrm{g} \mathrm{cm}^{-2}\right)$.

Figure 4 shows the net growth rates $(k)$ of the dominant species participating in the equilibrial assemblages during the two periods. In the first year, Navicula lanceolata $(k=0.09)$ and Surirella brebissoni $(k=0.07)$ had high net growth rates. Planothidium frequentissimum $(k=0.04)$ and Gomphonema parvulum $(k=0.05)$ exhibited lower net growth rates. This situation was different in the second year: Fragilaria vaucheriae $(k=0.10)$ had the highest, while Nitzschia linearis had the lowest $(k=0.03)$ net growth rate. Navicula lanceolata and Gomphonema olivaceum had similar net growth rates $(k=0.04)$. In this year, the net growth rates of Navicula cryptotenella and Gomphonema parvulum were higher $\left(k_{\mathrm{NCRY}}=0.08, k_{\mathrm{GPAR}}=0.07\right)$ than Navicula gregar $i a$ or Gomphonema olivaceum $\left(k_{\mathrm{NGREG}}=0.05\right.$, $\left.k_{\mathrm{GOLI}}=0.04\right)$. In the second year, Navicula lanceolata and Gomphonema olivaceum $(k=0.04)$ showed lower net growth rates, while Fragilaria vaucheriae $(k=0.10)$ and Gomphonema parvulum $(k=0.07)$ had higher net growth rates than in the first year. Cocconeis placentula sensu lato had medium net growth rate in both years.

\section{Chemical and physical parameters}

Table 1 summarizes the coefficients of variation (CV) of the parameters. The most balanced factors $(<20 \%)$ were the $\mathrm{DO}, \mathrm{DO} \%$ and $\mathrm{pH}$. Temperature, conductivity, alkalinity, $\mathrm{Cl}^{-}$concentration, and discharge were also mainly homogeneous except some shorter intervals. The measured phosphorus and nitrogen forms, $\mathrm{SO}_{4}{ }^{2-}$, SRSi concentration, and COD were extremely variable $(>20 \%)$ during the entire period.

In the first year (2008-2009), the DO, conductivity, discharge, and SRP fluctuated (compared to the equilibrium state) in most cases (7-9 out of 13), but the changes of $\mathrm{NO}_{3}{ }^{-}$ion and TP were also important (5-6 out of 13). The $\mathrm{CV}$ of $\mathrm{NH}_{4}{ }^{+}, \mathrm{SRSi}, \mathrm{SO}_{4}{ }^{2-}$ and alkalinity did not exceed the values measured in the supposed equilibrium states. If we consider each month, most of the parameters fluctuated at the same time in September (8 variables out of 16), in April, August, December, and January (5-6 out of 16). In most cases, three or four variables fluctuated at the same time. In the second year, DO (8 months out of 13) fluctuated in most of the cases, while the other environmental parameters did not change or not significantly (1-3 out of 13) compared to the steady states. Contrary to the previous year, commonly 1-3 parameters fluctuated a lot together in the month and the highest number of variables (4 out of 16) changed together in December.

Taking all the three conditions of establishment of the equilibrium status into consideration (Tables 2,3), in most cases (10 times out of 13) only two conditions, while in October and February none of the conditions was fulfilled at the same time. Equilibrium state (when all of the conditions were realized) was found only in July. In the second year, three times (June, September, October) none of the conditions was fulfilled. In July and August just one condition, while in 6 further months two conditions were fulfilled. The three 


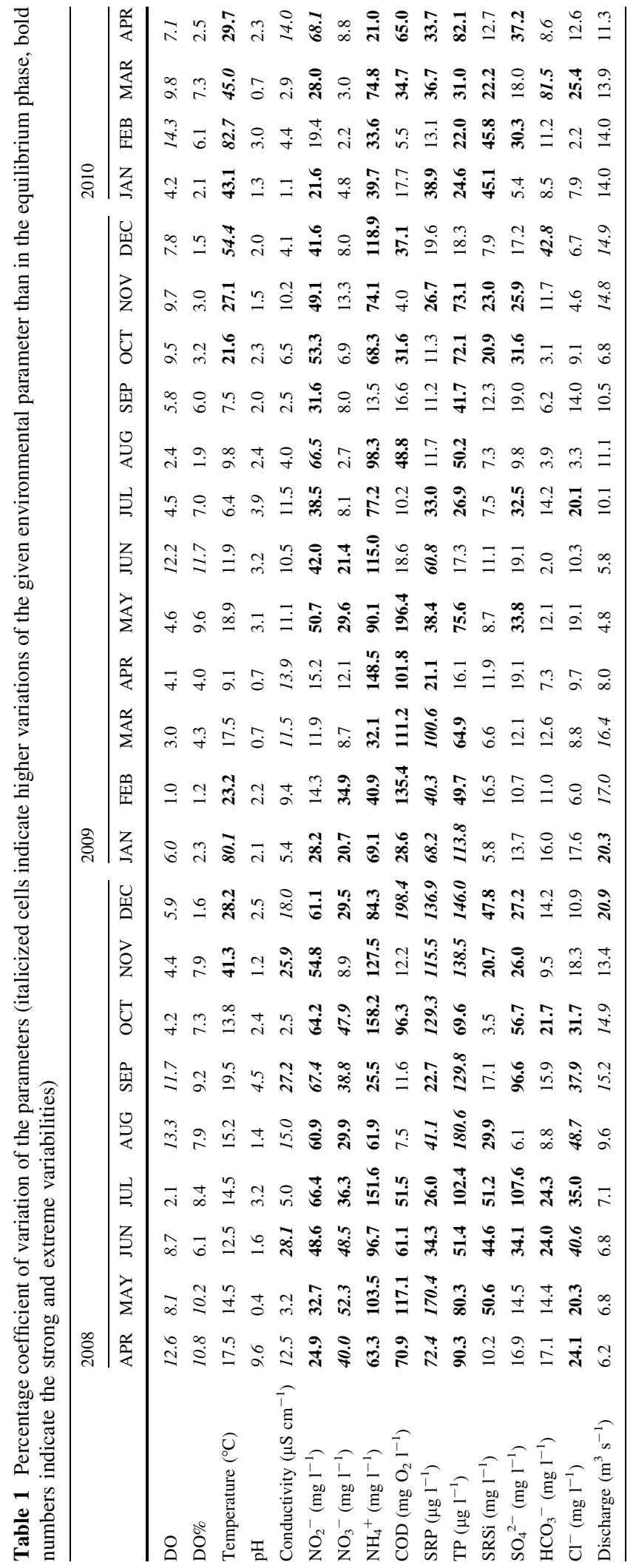


Table 2 Equilibrium conditions in the first year (+ fulfilled, - not fulfilled)

\begin{tabular}{|c|c|c|c|c|c|c|c|c|c|c|c|c|c|}
\hline & APR & MAY & JUN & JUL & AUG & SEP & OCT & NOV & DEC & JAN & FEB & MAR & APR \\
\hline $\begin{array}{l}\text { 1st Condition (max. } 5 \text { species contribute more } \\
\text { than } 80 \% \text { of total biomass) }\end{array}$ & + & + & + & + & + & + & - & + & + & + & - & + & + \\
\hline 2nd Condition (for at least 4 weeks) & + & + & + & + & + & + & - & + & + & + & - & + & + \\
\hline $\begin{array}{l}\text { 3rd Condition (without significant variation in } \\
\text { total biomass) }\end{array}$ & - & - & - & + & - & - & - & - & - & - & - & - & - \\
\hline
\end{tabular}

Table 3 Equilibrium conditions in the second year (+ fulfilled, - not fulfilled)

\begin{tabular}{|c|c|c|c|c|c|c|c|c|c|c|c|c|c|}
\hline & APR & MAY & JUN & JUL & AUG & SEP & OCT & NOV & DEC & JAN & FEB & MAR & APR \\
\hline $\begin{array}{l}\text { 1st Condition (max. } 5 \text { species contribute more } \\
\text { than } 80 \% \text { of total biomass) }\end{array}$ & + & + & - & - & - & - & - & + & + & + & + & + & + \\
\hline 2nd Condition (for at least 4 weeks) & + & + & - & - & - & - & - & + & + & + & + & + & + \\
\hline $\begin{array}{l}\text { 3rd Condition (without significant variation in } \\
\text { total biomass) }\end{array}$ & - & + & - & + & + & - & - & - & - & + & - & - & - \\
\hline
\end{tabular}

Table 4 The species composition in the equilibrium states (and its contribution to the total biomass)

\begin{tabular}{llll}
\hline & 1st Equilibrium phase & 2nd Equilibrium phase & 3rd Equilibrium phase \\
\hline Sp 1 & Cocconeis placentula sensu lato $(45.2 \%)$ & Cocconeis placentula sensu lato (79.4\%) & Navicula lanceolata (78.4\%) \\
Sp 2 & Fragilaria vauchariae $(13.7 \%)$ & & \\
Sp 3 & Navicula lanceolata $(10.1 \%)$ & \\
Sp 4 & Gomphonema parvulum $(6.8 \%)$ & \\
Sp 5 & Navicula gregaria $(3.3 \%)$ & \\
\hline
\end{tabular}

equilibrium conditions were realized at the same time only in May and January. Species composition in the equilibrium phases is given in Table 4.

\section{Discussion}

Heraclitus's evergreen wisdom "One cannot step into the same river twice" goes to philosophical depths, but even in its most immediate meaning it expresses the continuously changing nature of running waters. Here the word "river", small to large, cannot be replaced by the word "lake". Variability of running waters can be observed by naked eyes especially through changes in discharge, flow velocity, and suspended solids.

Many diatom species were identified early as good indicators of some major variables (for example salinity or conductivity) or the entire habitat (Hustedt, 1930). After recognizing a number of important properties of diatoms useful for monitoring water quality (like occurrence in almost all inland waters, high species number, relatively standard taxonomy, easy-to-archive slides, etc.), development of diatom indices started blossoming (see Whitton, 2012 for a summary), and this kind of research has been accelerating since issuing of the Water Framework Directive (WFD, 2000) that designated benthic microalgae as one of the five major biological quality elements. During the last 25 years, most studies on river diatoms were directly or indirectly related to application of the WFD including elaboration of national metrics, selection of relevant indices, improving assessments by intercalibration exercises, etc. (e.g. Kelly et al., 2009 and references cited therein). As case and comparative studies accumulated, doubts started to emerge about the overall applied methods and their appropriateness in assessing real ecological status. In his seminal paper, Kelly (2013) concluded that more 


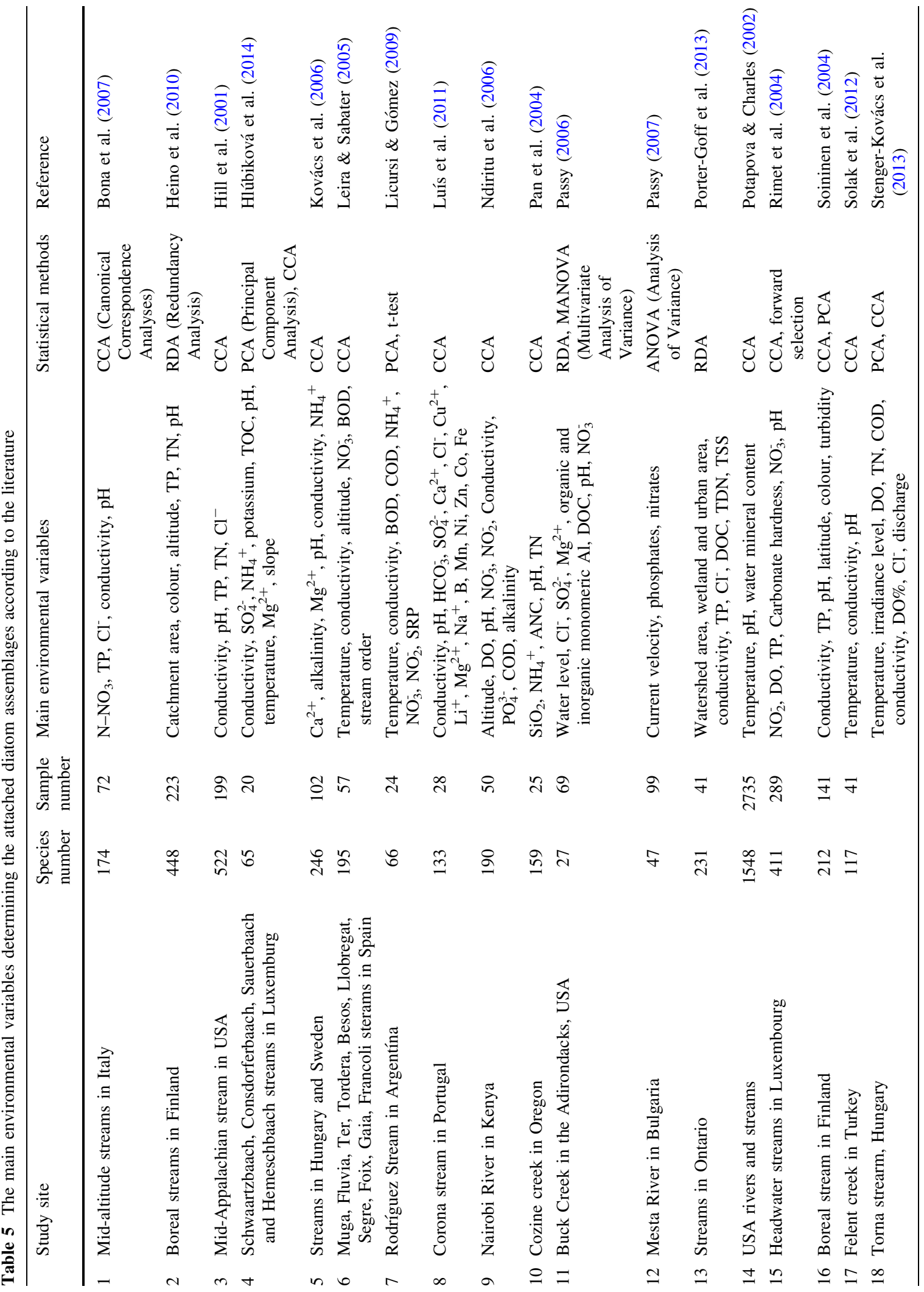


knowledge is needed about traits of phytobenthos, with deep roots in functional ecology to achieve a better coupling of cause and effect, similarly as has been done for benthic macroinvertebrates.

During the last 25 years, phytoplankton ecologists focused rather on coupling habitat properties with morphological and/or physiological traits of phytoplankton that resulted in three functional classifications (Reynolds et al., 2002; Salmaso \& Padisák, 2007; Kruk et al., 2010). Two of them are applied for the ecological status assessment according to the WFD (Padisák et al., 2006; Phillips et al., 2011). Additionally, much effort was dedicated to the understanding of the diversitydisturbance relationship (Reynolds et al., 1993; Sommer et al., 1993), and the closely related emergence of equilibrium states (Naselli-Flores et al., 2003).

According to the original assumptions (Sommer et al., 1993), progress towards an equilibrium state requires environmental constancy during a sufficiently long time for allowing selection of the best-fit species or species complexes (up to 5 according to reasons and considerations detailed in the introduction). In statistical models elaborated for explaining relationships between compositions of attached diatom assemblages and environmental variables, the following determinant groups were selected repeatedly (Table 5; and also see references therein):

- Variables describing a temporal scale (season), like temperature, DO, oxygen saturation

- Nutrient conditions (nitrate, nitrite, ammonium, $\mathrm{SRP}, \mathrm{SRSi}$ ) or trophic state (TN, TP) and nutrient ratios

- Variables describing ionic composition (conductivity, chloride, sulphate, some other elements)

- Acidity-alkalinity (pH, alkalinity, calcium concentration)

- Organic content (BOD, COD, colour, TOC, PON... etc.)

- Light conditions (turbidity, suspended solids)

- Spatial and land use descriptors (catchment, altitude, slope, urban areas, etc.) and in some special cases

- Toxic agents

- Interestingly, the probably most important physical variable (measured as discharge or flow velocity) is largely neglected.

Therefore, it seems reasonable to analyse constancy of such variables during the equilibrium phases found 
in this study. During the first equilibrium state (July, 2008), the most important variables determined by the PCA and CCA (Stenger-Kovács et al., 2013) changed significantly $(>20 \%)$ : Nitrogen forms showed approximately 36-152\%, COD 50\%, while $\mathrm{Cl}^{-}$exhibited $35 \% \mathrm{CV}$. Furthermore, extremely variable concentrations of phosphorus forms were recorded (SRP: $26 \%$, TP: $102.5 \%$ ). In the second one, similar trends were observed, but instead of $\mathrm{Cl}^{-}$, the $\mathrm{SO}_{4}{ }^{2-}$ concentration had higher CV. A decreasing fluctuation of these variables were detected in the third equilibrium phase (January, 2010), but the correlations of variation of these factors were still significant (20-40\%). Additionally in this month, the temperature, as another main environmental parameter, determined by PCA and CCA showed higher CV (43\%). Analyses of environmental constancy during equilibrium phases are not available in the literature; however, these data allow concluding that resilience of a developed equilibrium phase may ensure biotic constancy even though the underpinning environmental background fluctuates at higher amplitude.

The number of coexisting species varied between one and five (1st equilibrium state: Cocconeis placentula sensu lato, Fragilaria vaucheriae, Gomphonema parvulum, Navicula gregaria, and Navicula lanceolata; 2nd: Cocconeis placentula sensu lato; 3rd: Navicula lanceolata). This observation is similar to findings for phytoplankton: monodominance is more likely in such phases than coexistence of more than one species (Padisák et al., 2003). However, mechanisms resulting in equilibrium are more diverse than competitive exclusion (Rojo \& Álvarez-Cobelas, 2003). For example, during the second equilibrium phase disturbance intensities were rather high. Cocconeis placentula sensu lato is a fresh-brackish water diatom. It is a non-motile species, attaching by the valve face and mucilage to the substratum. Cocconeis placentula sensu lato is associated with low organic-matter content (Lange-Bertalot, 1979; Gómez, 1998; Kelly, 1998), and it is favoured by moderate or high nutrient concentrations (Yallop et al., 2009; Gómez \& Licursi, 2001). This is confirmed also by the IPS (Specific Pollution Index) indicator values (1.0) and taxon sensitivities (4.0), which mean that Cocconeis placentula sensu lato tolerates elevated concentrations of organically bound nitrogen. According to its autecological features, the high relative contribution to total biomass of this pioneer species (Hofmann et al., 2011) might be the result of its stress tolerance (sensu Borics et al., 2013) rather than of competitive exclusion.

During the 3rd equilibrium phase Navicula lanceolata built up 78.4\% of the total biomass (Table 4), and this period was characterized by highest environmental constancy. According to the slow net growth rates of the species, Navicula lanceolata can be characterized as a climax species. It is also a fresh-brackish species but typically occurs in cold waters, and it is motile (Hofmann et al., 2011). Its belonging to the motile guild (Stenger-Kovács et al., 2013) allows the species to resist against moderate water discharge. According to Kelly (1998) Navicula lanceolata is an organic-matter-pollution-tolerant species. As indicated in many works (e.g. Lange-Bertalot, 1979; Krammer \& Lange-Bertalot, 1999a), this species is more abundant at lower temperatures (the end of autumn, winter, and early spring). The IPS indicator value is 1.0 , the taxon sensitivity is 3.8 , and in this month the concentration of the nutrients were moderate or high, which also contributed to the increase of this species. In the absence of nutrient limitation, temperature was the primary factor allowing emergence of Navicula lanceolata. The species found in equilibrium states in this study are either stresstolerant or K-selected ones with low net growth rates in agreement with observations on phytoplankton (Padisák et al., 2003; Stoyneva, 2003). In our study, steady state did not occur during the colonization periods (when the diversity was low) in contrast of Hameed's (2003) study, where, paradoxically, the equilibrium state was suggested during the colonization period.

Overall, non-equilibrium states of the diatom assemblage were characteristic during this study. The Torna-stream is a fast-changing ecosystem like non-stratified lakes, with discharge as the major regulating environmental factor by affecting nutrient supplies and the light regime (Descy, 1993). Although there was no nitrogen or phosphorus limitation during the entire study, in the non-equilibrial phases 3 or more environmental parameters (mainly the conductivity, SRP, DO, discharge) changed significantly or the amplitudes of variation of fewer parameters were high at the same time.

Contrary to Reynolds' $(1984,1988)$ theoretical presumptions (river phytoplankton should be dominated by $r$, fast-growing species which are able to develop in a strongly disturbed and light-limited 
environment), Shannon diversity remained high during almost the entire first year, because disturbance reached intermediate intensities and frequencies, allowing smaller, fast-growing species to co-occur with the K-strategist species as described in the IDH. In the second period after the steady state in May, the diversity was high due to intensive disturbances which excluded the equilibrium phase. This maximal diversity collapsed in September, probably due to $\mathrm{Si}$ depletion. After it, despite that the environmental conditions were sufficient for the developing of the steady state, there was no sufficiently long undisturbed period which is necessary to reach it. Naselli-Flores et al. (2003) also concluded that, in the absence of disturbance, there should be enough time to progress towards the equilibrium state. For phytoplankton, 35-60 days were required to achieve equilibrium (Sommer, 1985, 1989; Reynolds, 1993; Padisák, 1994), but it appears reasonable that it should be longer for the periphyton because of the different (longer) generation times.

In most of the cases, changes in biomass prevented detection of the equilibrium phases. In both years, chlorophyll- $a$ concentrations continued increasing until autumn (September in the first year and November) and then restarted again in approximately February in both years, which could hardly be explained by Si utilization.

Similar to lakes in temperate regions, equilibrium phases in the diatom assemblage occurred only occasionally and were ephemeral but could develop both in relatively permanent and in highly variable environments (Mischke \& Nixdorf, 2003; NaselliFlores et al., 2003; O'Farell et al., 2003; Rojo \& Álvarez-Cobelas, 2003; Stoyneva, 2003). In the case of some water chemical parameters, threshold values could be defined: if the CV of conductivity $>14 \%$, $\mathrm{pH}>4 \%, \mathrm{NO}_{2}{ }^{-}>66.5 \%$ and $\mathrm{DO}>5.8 \%$, equilibrium state could not develop. The degree of change in these parameters alone was enough to prevent the development of an equilibrial phase. However, in other cases lower amplitude of variance was observed for two-three variables and their combined effect led to the non-equilibrium phase. Experiences on phytoplankton assemblages report on the climate determination of the probability of development of equilibrium states: they are more likely to occur and last longer in warmer climates (Komárková \& Tavera,
2003; Becker et al., 2008; Li et al., 2011). Such relationship is to be explored for stream diatoms.

As to the ecological status according to the WFD, there were no significant differences between the equilibrium and non-equilibrium phases since the IPS values varied between 3 and 4 independently from the equilibrial status.

The conclusions of our study on attached stream diatom assemblages are similar to those found in temperate lakes: equilibrium states are rare, unpredictable, ephemeral, may occur both in relatively stable and strongly fluctuating environments, and are mostly characterized by monodominance but, contrary to the phytoplankton, their establishment requires a longer time to develop corresponding to difference in generation times.

Acknowledgment The study was supported by the Hungarian National Science Foundation (OTKA K75552) and EU Societal Renewal Operative Program (TÁMOP-4.2.2.A-11/1/KONV2012-0064).

Open Access This article is distributed under the terms of the Creative Commons Attribution License which permits any use, distribution, and reproduction in any medium, provided the original author(s) and the source are credited.

\section{References}

Ács, É. \& K. T. Kiss, 1993. Effects of the water discharge on periphyton abundance and diversity in a large river (River Danube, Hungary). Hydrobiologia 249: 125-133.

APHA - American Public Health Association, 1998. Standard Methods for the Examination of Water and Wastewater, 20th ed. United Book Press, Baltimore, MD.

Becker, V., V. L. M. Huszar, L. Naselli-Flores \& J. Padisák, 2008. Phytoplankton equilibrium phases during thermal stratification in a deep subtropical reservoir. Freshwater Biology 53: 952-963.

Bona, F., E. Falasco, S. Fassina, B. Griselli \& G. Badino, 2007. Characterization of diatom assemblages in mid-altitude streams of NW Italy. Hydrobiologia 583: 265-274.

Borics, G., G. Várbíró \& J. Padisák, 2013. Disturbance and stress - different meanings in ecological dynamics? Hydrobiologia 711: 1-7.

Connell, J., 1978. Diversity in tropical rain forests and coral reefs. Science 199: 1304-1310.

Descy, J.-P., 1993. Ecology of the phytoplankton of the River Moselle: effects of disturbances on community structure and diversity. Hydrobiologia 249: 111-116.

Gómez, N., 1998. Use of epipelic diatoms for evaluation of water quality in the Matanza-Riachuelo (Argentina), a pampean plain river. Water Research 32: 2029-2034. 
Gómez, N. \& M. Licursi, 2001. The Pampean Diatom Index (IDP) for assessment of rivers and streams in Argentina. Aquatic Ecology 35: 173-181.

Hameed, H. A., 2003. The colonization of periphytic diatom species on artificial substrates in the Ashar canal, Basrah, Iraq. Limnologica 33: 54-61.

Hardin, G., 1960. The competitive exclusion theory. Science 131: 1292-1297.

Heino, J., L. M. Bini, S. M. Karjalainen, H. Mykra, J. Soininen, L. C. G. Vieira \& J. A. F. Diniz-Filho, 2010. Geographical patterns of micro-organismal community structure: are diatoms ubiquitously distributed across boreal streams? Oikos 119: 129-137.

Hill, B. H., R. J. Stevenson, Y. Pan, A. T. Herlihy, P. R. Kaufmann \& C. B. Johnson, 2001. Comparison of correlations between environmental characteristics and stream diatom assemblages characterized at genus and species levels. Journal of the North American Benthological Society 20: 299-310.

Hlúbiková, D., M. H. Novais, A. Dohet, L. Hoffmann \& L. Ector, 2014. Effect of riparian vegetation on diatom assemblages in headwater streams under different land uses. Science of the Total Environment 475: 234-247.

Hofmann, G., M. Werum \& H. Lange-Bertalot, 2011. Diatomeen im Süßwasser-Benthos von Mitteleuropa: Bestimmungsflora Kieselalgen für die ökologische Praxis: über 700 der häufigsten Arten und ihre Ökologie. A.R.G. Gantner Verlag Kommanditgesellschaft, Rugell.

Hustedt, F., 1930. Bacillariophyta (Diatomeae). In Pascher, A. (ed.), De Süsswasser-Flora Mitteleuropas. Verlag von Gustav Fischer, Jena.

Hutchinson, G. E., 1961. The paradox of plankton. American Naturalist 95: 137-147.

Juhász-Nagy, P., 1993. Notes on compositional diversity. Hydrobiologia 249: 173-182.

Kelly, M. G., 1998. Use of the trophic diatom index to monitor eutrophication in rivers. Water Research 32: 236-242.

Kelly, M., 2013. Data rich, information poor? Phytobenthos assessment and the Water Framework Directive. European Journal of Phycology 48: 437-450.

Kelly, M., S. Juggings, R. Guthrie, S. Pritchard, J. Jamieson, B. Rippey, H. Hirst \& M. Yallop, 2008. Assessment of ecological status in UK rivers using diatoms. Freshwater Biology 53: 403-422.

Kelly, M., C. Bennett, M. Coste, C. Delgado, F. Delmas, L. Denys, L. Ector, C. Fauville, M. Ferreol, M. Golub, A. Jarlman, A. Kahlert, J. Lucey, B. Ni Chathain, I. Pardo, P. Pfiester, J. Picinska-Faltinowicz, J. Rosebery, C. Schranz, J. Schaumburg, H. van Dam \& S. Vilbaste, 2009. A comparison of national approaches to setting ecological status boundaries in phytobenthos assessment for the European Water Framework Directive: results of an intercalibration exercise. Hydrobiologia 621: 169-182.

King, L., G. Clarke, H. Bennion, M. Kelly \& M. Yallop, 2006. Recommendations for sampling littoral diatoms in lakes for ecological status assessments. Journal of Applied Phycology 18: 15-25.

Komárková, J. \& R. Tavera, 2003. Steady state of phytoplankton assemblage in the tropical Lake Catemaco (Mexico). Hydrobiologia 502: 187-196.
Kovács, Cs, M. Kahlert \& J. Padisák, 2006. Benthic diatom communities along $\mathrm{pH}$ and $\mathrm{TP}$ gradients in Hungarian and Swedish streams. Journal of Applied Phycology 18: 105-117.

Krammer, K., H. Lange-Bertalot, 1991. Bacillariophyceae 3. Teil: Centrales, Fragilariaceae, Eunotiaceae. In Pascher, A. (eds), Süßwasserflora von Mitteleuropa Band 2/3. Gustav Fischer Verlag, Heidelberg Berlin.

Krammer, K. \& H. Lange-Bertalot, 1997. Bacillariophyceae 2. Teil: Bacillariaceae, Epithemiaceae, Surirellaceae. In Pascher, A. (ed.), Süßwasserflora von Mitteleuropa Band 2/2. Gustav Fischer Verlag, Heidelberg.

Krammer, K. \& H. Lange-Bertalot, 1999a. Bacillariophyceae 1. Teil: Naviculaceae. In Pascher, A. (ed.), Süßwasserflora von Mitteleuropa Band 2/1. Gustav Fischer Verlag, Heidelberg.

Krammer, K. \& H. Lange-Bertalot, 1999b. Bacillariophyceae 4. Teil: Achnanthaceae, Kritische Erganzungen zu Navicula und Gomphonema. In Pascher, A. (ed.), Süßwasserflora von Mitteleuropa Band 2/4. Gustav Fischer Verlag, Heidelberg.

Kruk, C., V. L. M. Huszar, E. T. H. M. Peeters, S. Bonilla, L. Costa, M. Lürling, C. S. Reynolds \& M. Scheffer, 2010. A morphological classification capturing functional variation in phytoplankton. Freshwater Biology 55: 614-627.

Lange-Bertalot, H., 1979. Pollution and tolerance of diatoms as criterion of water quality estimation. Nova Hedwigia 64: 285-304.

Lange-Bertalot, H., 2000a. Diatoms of European Inland Waters and Comparable Habitats. The genus Pinnularia, Vol. 1. A.R.G. Gantner Verlag K.G., Ruggell.

Lange-Bertalot, H., 2000b. Iconographia Diatomologica. Annotated Diatom Micrographs. Diatomeen der Anden, Vol. 9. Koeltz Scientific Books, Koenigstein.

Lange-Bertalot, H., 2001. Diatoms of European Inland Waters and Comparable Habitats. Navicula sensu stricto, 10 Genera Separated from Navicula sensu lato, Frustulia, Vol. 2. A.R.G. Gantner Verlag K.G., Ruggell.

Lange-Bertalot, H., 2002. Diatoms of European Inland Waters and Comparable Habitats. Cymbella, Vol. 3. A.R.G. Gantner Verlag K.G., Ruggell.

Lange-Bertalot, H., 2004. Iconographia Diatomologica. Annotated Diatom Micrographs. Ecology-Hydrogeology-Taxonomy, Vol. 13. Koeltz Scientific Books, Koenigstein.

Lange-Bertalot, H., 2008. Iconographia Diatomologica. Annotated Diatom Micrographs. Diatoms of North America, Vol. 17. Koeltz Scientific Books, Koenigstein.

Látos, S, 2012. Különböző érdességű felületen növő algabevonat klorofill- $a$ tartalmának és kovaalga fejösszetételének vizsgálata. Diploma thesis, University of Pannonia.

Leira, M. \& S. Sabater, 2005. Diatom assemblages distribution in Catalan rivers, NE Spain, in relation to chemical and physiographical factors. Water Research 39: 73-82.

Li, J., L. J. Xiao \& B. P. Han, 2011. Steady-state analysis of phytoplankton communities in summer in a meso-eutrophic reservoir, Southern China. Chinese Journal of Applied \& Environmental Biology 17: 833-838.

Licursi, M. \& N. Gómez, 2009. Effects of dredging on benthic diatom assemblages in a lowland stream. Journal of Environmental Management 90: 973-982. 
Lorenzen, C. J., 1967. Determination of chlorophyll and phaeopigments: spectrophotometric equations. Limnology and Oceanography 12: 343-346.

Luís, A. T., P. Teixeira, S. F. P. Almeida, J. X. Matos \& E. F. Silva, 2011. Environmental impact of mining activities in the Lousal area (Portugal): chemical and diatom characterization of metal-contaminated stream sediments and surface water of Corona stream. Science of the Total Environment 409: 4312-4325.

Malthus, T. R., 1873. An Essay on the Principle of Population. Random House, New York.

Minitab Inc., Minitab 15, Statistical Software for Windows. Minitab Inc., State College, PA. http://www.minitab.com/.

Mischke, U. \& B. Nixdorf, 2003. Equilibrium phase conditions in shallow German lakes: how cyanoprokaryota species establish a steady state phase in late summer. Hydrobiologia 502: 123-132.

Morabito, G., A. Oggioni \& P. Panzani, 2003. Phytoplankton assemblage at equilibrium in large and deep subalpine lakes: a case study from Lago Maggiore (N. Italy). Hydrobiologia 502: 37-48.

Naselli-Flores, L., J. Padisák, M. T. Dokulil \& I. Chorus, 2003. Equilibrium/steady-state concept in phytoplankton ecology. Hydrobiologia 502: 395-403.

Ndiritu, G. G., N. N. Gichuki \& L. Triest, 2006. Distribution of epilithic diatoms in response to environmental conditions in an urban tropical stream, Central Kenya. Biodiversity and Conservation 15: 3267-3293.

Nixdorf, B., U. Mischke \& J. Rücker, 2003. Phytoplankton assemblages and steady state in deep and shallow eutrophic lakes - an approach to differentiate the habitat properties of Oscillatoriales. Hydrobiologia 502: 111-121.

O'Farell, I., R. Sinistro, I. Izaguirre \& F. Unrein, 2003. Do steady state assemblages occur in shallow lentic environments from wetlands? Hydrobiologia 502: 197-209.

Odum, E. P., 1969. The strategy of ecosystem development. Science 164: 262-270.

Odum, E. P., 1971. Fundamentals of Ecology, 3rd ed. Saunders, Philadelphia.

Padisák, J., 1994. Identification of relevant time-scale in nonequilibrium community dynamics: conclusions from phytoplankton surveys. New Zealand Journal of Ecology 18: 169-176.

Padisák, J., G. Borics, G. Fehér, I. Grigorszky, I. Oldal, A. Schmidt \& Zs Zámbóné-Doma, 2003. Dominant species, functional assemblages and frequency of equilibrium phases in late summer phytoplankton assemblages in Hungarian small shallow lakes. Hydrobiologia 502: 157-168.

Padisák, J., I. Grigorszky, G. Borics \& É. Soróczki-Pintér, 2006. Use of phytoplankton assemblages for monitoring ecological status of lakes within the Water Framework Directive: the assemblage index. Hydrobiologia 553: 1-14.

Pan, Y., A. Herlihy, P. Kaufmann, J. Wigington, J. Sickle \& T. Moser, 2004. Linkages among land-use, water quality, physical habitat conditions and lotic diatom assemblages: a multi-spatial scale assessment. Hydrobiologia 515: 59-73.

Passy, S. I., 2006. Diatom community dynamics in streams of chronic and episodic acidification: the roles of environment and time. Journal of Phycology 42: 312-323.
Passy, S. I., 2007. Diatom ecological guilds display distinct and predictable behavior along nutrient and disturbance gradients in running waters. Aquatic Botany 86: 171-178.

Phillips, G., G. Morabito, L. Carvalho, A. Lyche Solheim, B. Skjelbred, J. Moe, T. Andersen, U. Mischke, C. de Hoyos, G. Borics, 2011. Wiser Deliverable D3.1-1: Report on lake phytoplankton composition metrics, including a common metric approach for use in intercalibration by all GIGs. Project co-funded by the European Commission within the 7th Framework Programme. http://www.wiser.eu/ download/D3.1-1_draft.pdf.

Phycology Section, Patrick Center for Environmental Research, 2001. Biovolumes of algal taxa in samples collected by the USGS NAWQUA program. The Academy of Natural Sciences, Philadelphia.

Porter-Goff, E. R., P. C. Frost \& M. A. Xenopoulos, 2013. Changes in riverine benthic diatom community structure along a chloride gradient. Ecological Indicators 32: 97-106.

Potapova, M. G. \& D. F. Charles, 2002. Benthic diatoms in USA rivers: distributions along spatial and environmental gradients. Journal of Biogeography 29: 167-187.

Reynolds, C. S., 1984. Phytoplankton periodicity: the interactions of form, function and environmental variability. Freshwater Biology 14: 111-142.

Reynolds, C. S., 1988. Functional morphology and the adaptive strategies of freshwater phytoplankton. In Sandgren, C. D. (ed.), Growth and Reproductive Strategies of Freshwater Phytoplankton. Cambridge University Press, Cambridge.

Reynolds, C. S., 1993. Scales of disturbance and their role in plankton ecology. Hydrobiologia 249: 157-171.

Reynolds, C. S., J. Padisák \& U. Sommer, 1993. Intermediate disturbance in the ecology of phytoplankton and the maintenance of species diversity: a synthesis. Hydrobiologia 249: 183-188.

Reynolds, C. S., V. Huszar, C. Kruk, L. Naselli-Flores \& S. Melo, 2002. Towards a functional classification of the freshwater phytoplankton. Journal of Plankton Research 24: 417-428.

Richerson, P. J., R. Armstrong \& C. R. Goldman, 1970. Contemporaneous disequilibrium: a new hypothesis to explain the paradox of the plankton. Proceedings of the National Academy of Sciences USA 67: 1710-1714.

Rimet, F., L. Ector, H. M. Cauchie \& L. Hoffmann, 2004. Regional distribution of diatom assemblages in the headwater streams of Luxembourg. Hydrobiologia 520: 105-117.

Rojo, C. \& M. Álvarez-Cobelas, 2003. Are there steady state phytoplankton assemblages in the field? Hydrobiologia 502: 13-36.

Salmaso, N. \& J. Padisák, 2007. Morpho-Functional Groups and phytoplankton development in two deep lakes (Lake Garda, Italy and Lake Stechlin, Germany). Hydrobiologia 578: 97-112.

Shelly, T. E., 1979. The effect of rock size upon the distribution of species of Orthocladiinae (Chironomidae: diptera) and Baetis intercalaris McDunnough (Baetidae: Ephemeroptera). Ecological Entomology 4: 95-100.

Soininen, J., R. Paavola \& T. Muotka, 2004. Benthic diatom communities in boreal streams: community structure in 
relation to environmental and spatial gradients. Ecography 27: 330-342.

Solak, C. N., S. Barinova, É. Ács \& H. Dayioğlu, 2012. Diversity and ecology of diatoms from Felent creek (Sakarya river basin), Turkey. Turkish Journal of Botany 36: 191-203.

Sommer, U., 1985. Comparison between steady state and nonsteady state competition: experiments with natural phytoplankton. Limnology and Oceanography 30: 335-346.

Sommer, U., 1989. The role of competition for resources in phytoplankton species succession. In Sommer, U. (ed.), Plankton Ecology - Succession in Plankton Communities. Springer, Berlin: 57-106.

Sommer, U., J. Padisák, C. S. Reynolds \& P. Juhász-Nagy, 1993. Hutchinson's heritage: the diversity-disturbance relationship in phytoplankton. Hydrobiologia 249: 1-7.

Stenger-Kovács, C., E. Lengyel, L. O. Crossetti, V. Üveges \& J. Padisák, 2013. Diatom ecological guilds as indicators of temporally changing stressors and disturbances in the small Torna-stream, Hungary. Ecological Indicators 24: 138-147.

Stoyneva, M. P., 2003. Steady-state phytoplankton assemblages in shallow Bulgarian wetlands. Hydrobiologia 502: 169-176.

Tett, P., M. Kelly \& G. M. Hornberger, 1975. A method for the spectrophotometric measurement of chlorophyll- $a$ and pheophytin- $a$ in benthic microalgae. Limnology and Oceanography 20: 887-896.

Turchin, P., 2001. Does population ecology have general laws? Oikos 94: 17-26.

Üveges, V. \& J. Padisák, 2011. Photosynthetic activity of epilithic algal communities in sections of the Torna stream
(Hungary) with natural and modified riparian shading. Hydrobiologia 679: 267-281.

Várbíró, G., G. Borics, B. Csányi, G. Fehér, I. Grigorszky, K. T. Kiss, A. Tóth \& É. Ács, 2012. Improvement of the ecological water qualification system of rivers based on the first results of the Hungarian phytobenthos surveillance monitoring. Hydrobiologia 695: 125-135.

Vilbaste, S. \& J. Truu, 2003. Distribution of benthic diatoms in relation to environmental variables in lowland streams. Hydrobiologia 493: 81-93.

Walker, C. E. \& Y. Pan, 2006. Using diatom assemblages to assess urban stream conditions. Hydrobiologia 561: 179-189.

Wetzel, R. G. \& G. E. Likens, 2000. Limnological Analyses. Springer, New York.

WFD, 2000. Directive of the European Parliament and of the Council 2000/60/EC. Establishing a framework for community action in the field of water policy. European Union, Luxembourg, PE-CONS 3639/1/00 REV 1.

Whitton, B., 2012. Changing approaches to monitoring during the period of the 'Use of Algae for Monitoring Rivers' symposia. Hydrobiologia 695: 7-16.

Wilson, J. B., 1990. Mechanisms of species coexistence: twelve explanations for Hutchinson's 'paradox of the plankton': evidence from New Zealand plant communities. New Zealand Journal of Ecology 13: 17-42.

Winter, J. G. \& H. C. Duthie, 2000. Stream epilithic, epipelic and epiphytic diatoms: habitat fidelity and use in biomonitoring. Aquatic Ecology 34: 345-353.

Yallop, M., H. Hirst, M. Kelly, S. Juggins, J. Jamieson \& R. Guthrie, 2009. Validation of ecological status concepts in UK rivers using historic diatom samples. Aquatic Botany 90: 289-295. 